\title{
Income Distribution, Political Instability, and Investment
}

\section{Citation}

Alesina, Alberto, and Roberto Perotti. 1996. Income distribution, political instability, and investment. European Economic Review 40(6): 1203-1228.

\section{Published Version}

http://dx.doi.org/10.1016/0014-2921(95)00030-5;doi:10.1016/0014-2921(95)00030-5

\section{Permanent link}

http://nrs.harvard.edu/urn-3:HUL.InstRepos:4553018

\section{Terms of Use}

This article was downloaded from Harvard University's DASH repository, and is made available under the terms and conditions applicable to Other Posted Material, as set forth at http:// nrs.harvard.edu/urn-3:HUL.InstRepos:dash.current.terms-of-use\#LAA

\section{Share Your Story}

The Harvard community has made this article openly available.

Please share how this access benefits you. Submit a story.

Accessibility 


\title{
NBER WORKING PAPER SERIES
}

\section{INCOME DISTRIBUTION, POLITICAL INSTABILITY, AND INVESTMENT}

\author{
Alberto Alesina \\ Roberto Perotti
}

Working Paper No. 4486

\author{
NATIONAL BUREAU OF ECONOMIC RESEARCH \\ 1050 Massachusetts Avenue \\ Cambridge, MA 02138 \\ October, 1993
}

\begin{abstract}
Alberto Alesina gratefully acknowledges financial support from the Institute for Policy Research. We thank Edgar Ariza-Nino, Gilbert Metcalf, Fabio Schiantarelli, Joseph Stiglitz and participants in seminars at Berkeley, Harvard, IGIER, NBER and at the 1993 AEA meetings for useful comments. Robert Barro and Marianne Fay kindly made available recently assembled data. Some of the work was completed while we were visiting IGIER in Milan. We thank this institution for its hospitality. Any opinions expressed are those of the authors and not those of the National Bureau of Economic Research.
\end{abstract}




\title{
INCOME DISTRIBUTION, POLITICAL INSTABILITY, AND INVESTMENT
}

\begin{abstract}
This paper successfully tests on a sample of 70 countries for the period 1960-85 the following hypotheses. Income inequality, by fueling social discontent, increases socio-political instability. The latter, by creating uncertainty in the politico-economic environment, reduces investment. As a consequence, income inequality and investment are inversely related. Since investment is a primary engine of growth, this paper identifies a channel for an inverse relationship between income inequality and growth.

We measure socio-political instability with indices which capture the occurrence of more or less violent phenomena of political unrest and we test our hypotheses by estimating a twoequation model in which the endogenous variables are investment and an index of socio-political instability.

Our results are robust to sensitivity analysis on the specification of the model and the measure of political instability, and are unchanged when the model is estimated using robust regression techniques.
\end{abstract}

\author{
Alberto Alesina \\ Department of Economics \\ Harvard University \\ Cambridge, MA 02138 \\ and NBER
}

\author{
Roberto Perotti \\ Department of Economics \\ Columbia University \\ New York, NY 10027
}




\section{Introduction.}

This paper studics the effects of income distribution on investment, by focusing on political instability as the channel which links these two variables. Income inequality increases social discontent and fuels social unrest. The latter, by increasing the probability of coups, revolutions, mass violence or, more generally, by increasing policy uncertainty and threatening property rights, has a negative effect on investment and, as a consequence, reduces growth.

Several authors have recently argued that income inequality is harmful for growth: in more unequal societies, the demand for fiscal redistribution financed by distortionary taxation is higher, causing a lower rate of growth. ${ }^{1}$ Alesina and Rodrik $(1991,1993)$ and Persson and Tabellini (1991) present reduced form regressions supportive of this hypothesis.

An important question, still unresolved empirically, is what exactly is the channel through which inequality harms investment and growth. Perotti (1992) explicitly investigates the fiscal channel described above, with, however, rather inconclusive results.

In this paper we emphasize and test a different link from income inequality to capital accumulation: political instability. Therefore, our paper is related to the research on the effects of political instability on growth. In particular, Barro (1991), Alesina, Ozler, Roubini and Swagel (1992), Block-Bomberg (1992) and Mauro (1993) find an inverse relationship between political instability and growth or investment, using different techniques, approaches and data ${ }^{2}$. Venieris and Gupta (1986) identify an inverse relationship between political instability and the savings rate.

We estimate on a cross-section of 70 countries for the period 1960-85 a two-equation system in which the endogenous variables are investment in physical capital and a mea-

\footnotetext{
${ }^{1}$ A non-exhaustive list of papers in this area includes Alesina and Rodrik (1991), (1993), Persson and Tabellini (1991), Bertola (1991) and Perotti (1993).

${ }^{2}$ Londegran and Poole $(1990,1991)$ in related work do not seem to find such evidence. For a discussion of their'results and comparisons with other literature see Alesina, Ozler, Roubini and Swagel (1992).
} 
sure of political instability. ${ }^{3}$ In our model, economic and political variables are jointly endogenous, an issue that has been generaily ignored in the recent literature on the political economy of growth. ${ }^{4}$ We are specifically interested in two questions:

(i) Does income inequality increase political instability?

(ii) Does political instability reduce investment?

According to our findings, the answer to both questions is "yes". First, more unequal societies are more politically unstable: in particular, our results suggest that political stability is enhanced by the presence of a wealthy middle class. Second, political instability has an adverse effect on investment and, therefore, on growth. Furthermore, these two effects (from inequality to instability, and from instability to investment) are not only statistically significant, but also economically significant.

We also test whether income distribution influences investment directly, in addition to the channel via politically instability. Several arguments would imply such a direct link. The first is a "Kaldorian" view (Kaldor (1956)) which holds that more inequality favors more accumulation, because the rich save more than the poor. As mentioned above, a second view is based on the effects of inequality on the demand for fiscal redistribution: this argument would imply an inverse relation between inequality and investment in physical capital (Alesina and Rodrik (1991), Bertola (1991), Persson and Tabellini (1991)). These two effects go in opposite directions and, in principle, they may cancel out. In fact, in our sample income distribution does not have any additional effect on investment after controlling for political instability.

This paper is organized as follows. Section 2 discusses problems of definition and measurement of political instability, and presents our index. Section 3 describes our data. Section 4 describes the specification of our two-equation system and discusses various identification issues. In section 5 we present our main results. Section 6 discusses several tests of sensitivity of our specification and the robustness of our results. The last

\footnotetext{
${ }^{3}$ The number of countries used in different specifications and different tests may vary slightly because of data availability. We have always chosen the largest sample of countries for which data were available.

${ }^{4}$ Exceptions are Londegran and Poole (1990), (1991), Alesina et al. (1992) and Block-Bomberg (1992).
} 
section concludes.

\section{Definition and measure of political instability.}

Social and political instability are variables that are hard to define and measure in a way which can be used for econometric work. Political instability can be viewed in two ways. The first one emphasizes executive instability. The second one is based upon indicators of social unrest and political violence.

The first approach defines political instability as the "propensity to observe government changes". These changes can be "constitutional", i.e. take place within the law, or "unconstitutional", i.e. they can be coups d'etat. The basic idea is that a high propensity to executive changes is associated with policy uncertainty and, in some cases, with threats to property rights. Note that the "propensity" to executive changes is distinct from the actual frequency of changes, and can be measured by probit regressions in which the probability of a change in the executive is related to several economic, socio-political and institutional variables.

For example Cukierman, Edwards and Tabellini (1992) and Edwards and Tabellini (1991) adopt this definition of instability in their work on inflation. One important issue, however, which these authors do not completely address is that of "joint endogeneity". On one hand, political instability affects aggregate economic outcome. On the other hand, the latter influences executive instability. Londegran and Poole (1990), (1991), Alesina et al. (1992) and Block-Bomberg (1992) have explicitly taken into account this problem in their work on executive instability and economic growth. All these authors estimate two-equations systems: one equation is a probit regression, which estimates the propensity to government changes, while the other is a regression for economic growth.

The sccond approach to measuring political instability does not focus directly on executive changes. Socio-political instability is measured by constructing an index which summarizes various variables capturing phenomena of social unrest. An important ref- 
erence on this point is Hibbs (1973), who uses the method of principal components to construct such index. More recently, Venieris and Gupta (1986), (1989), Gupta (1990), Barro (1991), Ozler and Tabellini (1991), Benhabib and Spiegel (1992) and Mauro (1993) have used several indices of socio-political instability as an explanatory variable in various regressions in which the dependent variable is growth, savings or investment. As emphasized above, joint endogeneity issues are crucial: in many cases there are good reasons to believe that the left hand side variable that one is attempting to explain as a function of socio-political instability (such as inflation, growth, investment etc.) is itself a determinant of social unrest ${ }^{5}$.

Which of the two approaches to measuring political instability described above is preferable is not clear a priori and may depend upon the specific issue under consideration. For instance, one may argue that, for a given level of expected government turnover, phenomena of social unrest do not have any direct impact on policy uncertainty, and therefore on economic decisions. This might be a strong but useful "identifying" assumption: policy changes relevant for economic decisions can occur only when governments change. On the other hand, one may argue that, particularly when it reaches very high levels, social unrest disrupts market activities and increases economic uncertainty above and beyond its direct effects on executive instability. Mass violence, civil wars, political disorder and physical threats to workers and entrepreneurs engaged in productive activities can have direct effects on productivity and therefore on the rate of return to investment.

This paper adopts the second approach to measuring political instability. We explicitly take into account problems of joint endogeneity by estimating a system of two equations in which the two endogenous variables are investment and an index of sociopolitical instability, SPI. The index is constructed by applying the method of principal component to the following variables: $A S S A S S$, the number of politically motivated assassinations; $D E A T H$, the number of people killed in conjunction with phenomena of

\footnotetext{
${ }^{5}$ Hibbs (1973) and Gupta (1990) do take this problem into account in their work.
} 
domestic mass violence; $S C O U P$, the number of successful coups; $U C O U P$, the number of attempted but unsuccessful coups; DICT, a dummy variable that takes the value of zero in democracies, .5 in "semi-democracies" and 1 in dictatorships. A "democracy" is defined as a country with free competitive elections; a semi-democracy is a country with some form of elections but with severe restrictions on political rights (for instance, Mexico); a dictatorship is a country without competitive elections ${ }^{6}$. All the variables are expressed as the average of annual values over the sample period, 1960-85. A more detailed definition of the variables used in this paper, including sources, is in Table $1^{7}$.

In choosing these variables to include in the index, we wanted to capture the idea of political instability viewed as a threat to property rights. Therefore we included two variables ( $A S S A S S$ and $D E A T H$ ) which capture phenomena of mass violence as well as violent and illegal forms of political expressions; we also included two variables (SCOUP and UCOUP) which capture illegal and typically violent transfers of executive power, successful or attempted. The variable $D I C T$ is included in the $S P I$ index mainly because of reporting problems: in most dictatorships the government controls the press and restricts the diffusion of information, particularly abroad. Thus, measures of sociopolitical unrest are likely to be under-reported, for propaganda reasons, in dictatorships.

The inclusion of DICT in our SPI index is also advisable for a second conceptual reason. Dictatorships are much more prone to be overthrown by extremists than stable democracies. That is, for the same level of observed political violence, the likelihood of a violent overthrown of the government with a breakdown of legality is higher in a dictatorship.

Applying the method of principal components ${ }^{8}$ to the five variables listed above leads

\footnotetext{
${ }^{6}$ This variable is obtained from Alesina et al. (1992)

${ }^{7}$ The variables $A S S A S S$ and $D E A T H$ are the total number of assassinations and deaths, respectively, rather than their per capita values. Conceptually, it is not clear which measure is more appropriate. Therefore, we constructed a second index of socio-political instability, using assassinations and deaths per capita, and our results did not change. The index that appears throughout the paper is constructed from the variables not in per capita terms.

${ }^{8}$ The method of principal components is used to describe a set of variables with a set of variables of lower dimensionality. This method locates $n$ linear combinations ("principal components") of the $n$ columns of the $X^{\prime} X$ matrix, all orthogonal to each other, with the following property: the first principal component
} 
to the following index of socio-political instability:

$$
S P I=1.86 A S S A S S+1.28 D E A T H+7.5 S C O U P+7.09 U C O U P+5.04 D I C T
$$

This $S P I$ index is related, but far from identical, to indices recently proposed by Venieris and Gupta (1986) and Gupta (1990), which we used in previous versions of this paper, and is somewhat different from Hibbs' (1973) index. Section 6 discusses the robustness of our results to the use of these alternative indices and to small changes in the specification of our index.

\section{Data and sample period.}

We perform cross sectional regressions using a sample of 70 countries for the period 1960-1985. The binding constraint on the number of countries is the data availability. We have income distribution data for 72 countries, but for only 70 of these we have data on political instability. We use the same data on income distribution assembled by Perotti (1992) which is very similar to the data set used by Alesina and Rodrik (1991). The main source of these data is Jain $(1975)^{9}$. The income distribution data consists of the income shares of the five quintiles of the population, measured as close as possible

$p_{1}$ minimizes $\operatorname{tr}\left(X-p_{1} a_{1}^{\prime}\right)^{\prime}\left(X-p_{1} a_{1}^{\prime}\right)$, where $a_{1}$ is the eigenvector of the $X^{\prime} X$ matrix associated with the largest eigenvalue. Intuitively, $p_{1}$ summarizes the $n$ variables in $X$ by giving the best linear description of the columns of $X$ in a least squares sense. The second principal component $p_{2}$ also describes what is not "captured" by the first component $p_{1}$ by minimizing the sum of squared residuals after subtracting $p_{1}$, i.e. $p_{2}$ minimizes $\operatorname{tr}\left(X-p_{1} a_{1}^{\prime}-p_{2} a_{2}^{\prime}\right)^{\prime}\left(X-p_{1} a_{1}^{\prime}-p_{2} a_{2}^{\prime}\right)$, where $a_{2}$ is now the eigenvector associated with the second largest eigenvalue, and so on. We use the first principal component of the five variables listed in the text as our SPI index. One can measure the contribution of the first principal component to explaining the total variability of the original variables, which is captured by the expression $\operatorname{tr} X^{\prime} X$. It can be shown that the contribution of the first principal component to the reduction of this variability is $\operatorname{tr} X^{\prime} X-\lambda_{1}$, where $\lambda_{1}$ is the highest eigenvalue. Because we standardize all our variables, the variance explained by the first principal component is generally quite low, between .3 and .4. If we had not standardized our variables, the first principal component would have been practically identical to the variable with the highest order of magnitude, in our case DEATHS. See Theil (1971), Chapter 1, for a brief description of the method of principal components.

${ }^{9}$ For a more complete description of sources of income distribution papers see the Appendix of this paper and Perotti (1992) 
to the beginning of each sample period, 1960. In our specification, income distribution is treated as predetermined; therefore, it is appropriate to use this variable measured at the beginning of the sample period.

The binding constraint on the initial date of the sample period is the availability of economic data. We use the same data employed by Barro (1991) and Perotti (1992). The end of our sample period (1985) is imposed by the availability of socio-political variables. The list of these variables is included in Table 1, as well.

Table 2 reports the average of our $S P I$ index for the sample 1960-85, ordered from the poorest to the richest country, in terms of their per capita income in 1960. This ordering immediately highlights a positive correlation between poverty and socio-political instability. Furthermore, a few countries suggest interesting observations. Japan has a much lower index of instability than countries at comparable level of development in 1960. Thirty years later this country is one of the richest in the world. The opposite observation holds for Argentina: it has the second highest SPI index and from 1960 to 1985 it has dropped several steps in the income ladder. Not surprisingly, the most stable countries are OECD democracies, even though several LDC's, such as Botswana, are also relatively stable. The case of Venezuela is also interesting: in 1960 it had the fifth highest per capita income in the sample, but a much higher $S P I$ index than the countries in the same group.

Table 3 reports the summary statistics for our variables and Table 4 highlights simple correlations between them. The two key correlations for our purposes are those between $S P I$ and investment, $I N V$, and between $S P I$ and $M I D C L A S S$, which represents the share of total income of the third and fourth quintiles of the population.

Both correlations have a value of about -.4. These signs are consistent with our hypothesis, namely that socio-political instability depresses investment and income inequality makes the socio-political environment more unstable. Also, SPI is negatively correlated with both the level of income and the level of education. However, the latter two variables are highly correlated with each other. Note that MIDCLASS has a much 
higher correlation with secondary school enrollment than with primary school enrollment. This correlation suggests, perhaps, that if the middle class is sufficiently well off, they can obtain for their children a level of education beyond the primary one. Because of this correlation, and because our sample includes several LDC's in which enrollment ratios in secondary schools in 1960 were extremely small, we prefer to use primary school enrollment as our measure of education. Finally, in our sample $M I D C L A S S$ has a correlation of -.93 with the share of the richest quintile. This implies that an increase in the share of the middle class is associated, on average, with essentially a one for one decrease in the share of the richest quintile. This is the main reason why the two variables do not appear at the same time in our regressions.

\section{Model specification.}

Our hypothesis is that income inequality increases socio-political instability and the latter reduces the propensity to invest. A large group of impoverished citizens, facing a small and very rich group of well-off individuals is likely to become dissatisfied with the existing socio-economic status quo and demand radical changes, so that mass violence and illegal seizure of power are more likely than when income distribution is more equitable. Several arguments justify the second link, from political instability to investment. The most compelling one emphasizes the effect of instability on uncertainty: in a more uncertain environment, investors may choose to postpone projects, invest abroad (capital llights) or simply consume more. A high value of the SPI index implies high uncertainty for two reasons. First, when social unrest is widespread, the probability of the government being overthrown is higher, making the course of future economic policy and even protection of property rights more uncertain. Second, social unrest may imply direct disruptions of productive activities. Third, the occurrence of attempted or successful coups indicates a propensity to abandon the rule of law and therefore, in principle, a threat to established property rights. 
We capture these two effects in the following basic specification of a simple bivariate simultaneous equation model in $S P I$ and investment:

$$
\begin{aligned}
& I N V=\alpha_{0}+\alpha_{1} S P I+\alpha_{2} P R I M+\alpha_{3} P P P I D E++\alpha_{4} P P P I+\epsilon_{1} \\
& S P I=\beta_{0}+\beta_{1} P R I M+\beta_{2} G D P+\beta_{3} I N V+\beta_{4} M I D C L A S S+\epsilon_{2}
\end{aligned}
$$

The dependent variable in equation (2) is total investment $(I N V)$. We use total rather than private investment because the breakdown of investment between private and public is available only for 53 of the 70 countries of our sample and only from 1970 onward. Aside from considerations of data availability, there are reasons to believe that public investment as well as private investment should be negatively affected in periods of high socio- political instability. Since these are usually periods of high and contrasting demands on the government budget, public investment projects are likely to be reduced to make room for redistributive expenditure.

As discussed above, we expect $\alpha_{1}$ in the investment equation to be negative. The variable PRIM (the enrollment ratio in primary school in 1960) is a proxy for human capital. ${ }^{10}$ Complementarity between physical and human capital would imply a positive sign for $\alpha_{2}$. The two variables PPPI (the PPP value of the investment deflator in 1960 relative to that of the U.S.) and PPPIDE (the magnitude of the deviation of PPPI from the sample mean) capture the effects of domestic distortions which obviously would affect investment directly. Note that this specification leads to a reduced form that is very similar to the investment equation in Barro (1991) (The three critical points of departure from that regressions are that we measure political instability differently, endogenize the $S P I$ index and introduce an income distribution variable).

Income distribution may affect investment directly, not only through political insta-

\footnotetext{
${ }^{10}$ In addition to providing new measures of primary enrollment, Barro and Lee (1993) have recently estimated several stock measures of human capital, and they kindly made all their data available to us. We prefer to use their primary enrollment ratio which is not an estimate but a direct observation. When we use their estimated human capital stock our regressions are less successful, possibly because of measurement errors in the constructed stock variables.
} 
bility, but also through two additional channels. The first one is a "Kaldorian" saving function. According to Kaldor (1956), the "capitalists" save more in proportion to their income than the "workers". Thus, the higher is the share of the top quintile, i.e. the more unequal is the distribution of income, the higher is investment. On the other hand, Alesina and Rodrik (1991) and Bertola (1991) argue that the more unequal the distribution of income, the higher is the demand for fiscal redistribution through taxation of capital. The latter may depress investment by increasing the tax burden on investors. In order to explore these direct channel we have run a second specification, in which we added an income distribution variable in the investment equation. However, since the two channels discussed above go in opposite direction, the sign of the associated coefficient is a priori ambiguous.

Turning to the $S P I$ equation, we included the variable $P R I M$ because a higher level of education may reduce political violence and channel political action within institutional rules (see Huntington (1968) or Hibbs (1973)). Therefore, we expect $\beta_{1}<0$. A similar argument justifies the inclusion of income per capita at the beginning of the period, GDP: the basic notion is that "good things go together", so that richer countries are more stable. Thus, $\beta_{2}$ should be negative according to this hypothesis. Investment is included to test whether rapidly growing economies tend to be more stable: on the one hand, more growth means more prosperity, less dissatisfaction and possibly more stability, implying a negative sign for $\beta_{3}$. On the other hand, periods of very high growth may temporarily lead to social disruptions and economic transformation which may actually increase political instability. Finally, as discussed at length above, we expect a positive relation between inequality and instability: accordingly, under the null hypothesis the sign of $\beta_{4}$ should be negative when an index of equality is used.

We have also built upon this basic specification by adding a few variables. We included a variable for urbanization in the $S P I$ equation: several political scientists (for instance, Huntington (1968) and Hibbs (1973)) have argued that more urbanized societies should be more politically unstable because political participation and social unrest are more 
likely to be higher in cities. Also, we included regional dummies in the $S P I$ equation for two reasons. First, cultural and/or historical reasons may influence the amount of sociopolitical unrest in different regions of the world. Second, in certain regions, particularly Africa, under-reporting of socio-political events can be particularly acute. Finally, we added in the SPI equation a variable that captures the degree of linguistic and ethnic fragmentation.

Before proceeding, it is appropriate to spend a few words to justify, on a priory grounds, our identifying assumptions. The first and crucial one is the exclusion of $P P P I D E$ and $P P P I$ from the SPI equation. These variables measure market distortions and the relative price of investment goods, both of which should have a direct effect on investment decisions and a much less clear-cut effect on social unrest. Second, we excluded $G D P$ from the investment equation. However, since this exclusion might be questionable, we reran our system with GDP in the investment equation, but our results remained generally unchanged. Third, there are more compelling reasons (discussed above) to introduce exhaustive regional dummies in the SPI equation than in the investment equation. Sensitivity analysis on these and other identifying assumptions are presented below in Section 6: our basic results are quite robust to changes in the specification of the system ${ }^{11}$.

\footnotetext{
"Our paper is somewhat related to recent work by Gupta (1990). Like us, Gupta estimates a structural model where income distribution affects political instability and the latter affects investment. Our specification, however, builds on the recent empirical literature on growth and differs substantially from Gupta's. Moreover, he has observations on income distribution for only 49 of the 104 countries in his sample. The remaining observations are obtained by regressing the existing sample of income distribution variables on a set of explanatory variables, and using the estimated coefficients to generate values for the missing observations. There is no need to underline the problems of this procedure. Finally, for reasons that are not clear to us, in all his regressions Gupta uses the 1970 value of the SPI index rather than its average on the estimation period as we do. These and other differences are sufficient to explain the difference in results between the two works: in fact, contrary to our results, in Gupta's book both income distribution and political instability turn out to be insignificant in explaining political instability and investment respectively.
} 


\section{Estimation results.}

This section describes the results of several basic specifications. Columns (1a) and (1b) of Table 5 report the estimates of equations (2) and (3). The two key coefficients are those that capture the effects of SPI on INV and of MIDCLASS on SPI. Both coefficients have the expected signs and are significant at the $5 \%$ level: socio-political instability depresses investment and a rich middle class reduces socio-political instability. A "healthy" middle class is conducive to capital accumulation because it creates conditions of social stability. As noted above, the share of income of the middle class has a correlation of almost -1 with the share of the richest quintile; thus, a wealthier middle class implies more equality in the distribution of income.

An increase by one standard deviation of the share of the middle class causes a decrease in the index of political instability of about 3.3, which corresponds to one fourth of its standard deviation. This in turn causes an increase in the share of investment in GDP of about one percentage point. Although not huge, the effect of income distribution on investment implied by these estimates is not negligible either, since the difference between the highest and lowest value of MIDCLASS in the sample is about 4 standard deviations. In addition, an exogenous increase in the $S P I$ index by one standard deviation causes a decrease in the share of investment in GDP of about 4 percentage points.

The coefficients on PRIM and PPPIDE in the investment equation have the expected signs and are significant at high levels of confidence: education has a positive effect on investment, while one of the proxies for market distortions, PPPIDE, has a negative effect on investment. The second proxy for market distortions, PPPI, is insignificant. ${ }^{12}$

The estimation results for the $S P I$ equation are also very sensible. Both GDP and $P R I M$ have a negative impact on $S P I$, although not strongly significant. As expected, richer countries and countries with higher levels of education are more stable. PRIM and GDP are highly correlated: if $P R I M$ is dropped from the SPI equation, the coefficient

\footnotetext{
(1991).

${ }^{12}$ Note that our results in the investment equation are consistent with the reduced form results in Barro
} 
of GDP becomes statistically significant, while all the other coefficients remain virtually unchanged (results are available upon request).

In columns (2a) and (2b) we add two regional dummies, $A S I A$ and $A F R I C A$, in the $S P I$ equation: our results are unchanged. In columns (3a) and (3b) we add a third regional dummy, $L A A M E R$. Now the effect of $S P I$ on investment is reinforced, but both the size and the t-statistics of the coefficient of MIDCLASS in the SPI equation drop substantially. This is hardly surprising, since the Latin America countries in the sample are more unstable than the average and, especially, have a particularly unequal distribution of income (see Table 3). Because of this pattern of correlations, by a simple omitted-variable argument the t-statistics on the variable $M I D C L A S S$ drops when $L A A M E R$ is also included in the sample.

A suggestive, although imperfect way to correct for this problem is to use the residual of the regression of LAAMER on MIDCLASS (and a constant) as our Latin American dummy. This orthogonalization eliminates the multicollinearity problem caused by the correlation between $M I D C L A S S$ and $L A A M E R$, although of course the estimate of the coefficient of MIDCLASS is no longer consistent. As columns (4a) and (4b) show, when we use this orthogonalized residual (ORTLAAMER) the coefficient of MIDCLASS increases sharply in absolute value and it becomes significant. ${ }^{13}$

\footnotetext{
${ }^{13}$ As mentioned above, the breakdown of total investment into private and public investment is available only for 53 countries and only from 1970 onward. We estimated the same specifications of Table 5 using the average rate of private investment in the $1970-85$ period with the following results: the effect of $S P I$ on investment remains large and statistically significant; the coefficient of MIDCLASS in the SPI equation has the correct sign but is not significant at conventional levels. We repeated the same regressions using total investment over the same sample 1970-85: the results were essentially identical to those obtained when using private investment. These findings (available upon request) suggest that the difference between the results of Table 5 and those obtained with private investment are due to the sample size but especially to the shorter time period. A fifteen year period (1970-85) may be too short for the type of structural, long-run relationship between inequality and instability that we are testing. Therefore, we feel that it is more reasonable to place more weight on the results obtained for the 1960-85 period.
} 


\section{Robustness and sensitivity analysis.}

First we tested the sensitivity of our results to the particular $S P I$ index used. In a previous version of this paper we used an index proposed by Gupta (1990): this index (SPIG) was obtained by applying the method of discriminant analysis to a larger sample than ours (about 100 countries). In addition to the variables used in our index ${ }^{14}$, Gupta includes: PROTEST, the number of political demonstrations against a government; $R I O T$, the number of riots; STRIKE, the number of political strikes; $A T T A C K$, the number of politically motivated attacks; EXECUTION, the number of politically motivated executions. Thus, our index differs from Gupta's for three reasons: his sample of countries is different, he uses discriminant analysis rather than the principal component method to construct it, and he includes many more variables. Despite these differences, the correlation of Gupta's index to ours is extremely high, about .8. Table 6 reports the results obtained when using Gupta's SPIG index in the same systems estimated in Table 5 .

Both the coefficient of the SPIG index in the investment equation and of MIDCLASS in the SPIG equation have the expected sign and are significant at conventional levels. Interestingly, the size of the coefficients are such that an increase in MIDCLASS by one standard deviation has roughly the same effects on SPIG and, through the latter, on investment as when our $S P I$ index is used. All the other coefficients exhibit patterns very similar to those of Table 5, with one significant difference: now the coefficient of MIDCLASS remains significant (with a t-statistics of - 1.85) even when the Latin American dummy variable is included (see column (3b)). A comparison of this result with the corresponding column of Table 5 highlights once more the effects of the correlation of $L A A M E R$ with all these indices of political instability. Depending on the index and the specification, either $L A A M E R$ is significant and $M I D C L A S S$ is not, or viceversa.

We have experimented by applying the principal component method to several combi-

\footnotetext{
${ }^{14}$ Note however that Gupta's measure of the variable $D I C T$ is slightly different from ours, although the two measures are highly correlated.
} 
nations of the long list of variables included in the Gupta's index. The pattern of results that we obtain (available upon request) can be summarized as follows. First, when we add RIOT and PROTEST to the list of variables of our SPI index, the effect of SPI on investment remains large and significant, while the effect of MIDCLASS on SPI becomes less strong. We believe this may be explained by some potential problems of these two variables. RIOT includes disturbances in prisons, that may occur in stable democracies. PROTEST includes forms of political expression that do not threaten property rights (for instance, a march in Washington D.C. to protest against racial discrimination). Our results also worsen, compared to those of Table 5, with indices that do not include successful and unsuccessful coups. This finding suggests that these two variables are crucial to capturing threats to property rights and policy uncertainty. Finally, if we leave out the variable $D I C T$, our results generally worsen.

In summary, it would appear that the kind of instability that increases with inequality and affects investment is the one that manifests itself in more violent forms (i.e. ASSASS rather than PROTEST) and which involves coups, i.e. illegal and often violent forms of transfer of power.

Table 7 displays several additional specifications that build upon the basic one. In this Table we use our SPI index, but the results (available upon request) are very similar with the $S P I G$ index ${ }^{15}$. In columns (1a) and (1b) we add $U R B$, a measure of urbanization, in the $S P I$ equation. This variable has a positive coefficient, marginally insignificant at standard confidence levels: as expected, urbanization tends to fuel social unrest. This result on urbanization is consistent with the arguments of Huntington (1968) and the empirical tests of Berg and Sachs (1988), who argue that urbanization leads to more social demands and political pressure for redistributive policies.

Columns (2a) and (2b) show the system with MIDCLASS in the investment equation. The coefficient on this variable is statistically insignificant, while all the other coeffcients are basically unaffected. This result has two possible interpretations. The

\footnotetext{
${ }^{15}$ We present the specification without $L A A M E R$ to avoid repeating our discussion on multicollinearity.
} 
first one is that the only effect of income inequality on capital accumulation goes through political instability. The second one is that, once political instability is controlled for, the "Kaldorian" effect and the fiscal redistribution effect offset each other.

In columns (3a) and (3b) we add the variable HOMOG in the SPI equation. This variable is defined as the fraction of the population (in 1960) belonging to the main ethnic and linguistic group. Thus, a lower value of this variable implies more ethnic fragmentation, which is likely to be a cause of political instability and mass violence (Hibbs (1973)). The coefficient on this variable has the expected sign but is not significant at conventional levels. Generally, depending on the other variables included in the regression, $H O M O G$ has a coefficient which is always negative (as expected) but with varying degrees of statistical significance.

We tried several additional permutations in the specification, using the two indices of political instability and various combinations of the variables discussed in Tables 5, 6 and 7. Our results (available upon request) confirm the robustness of our findings both on the effects of inequality on political instability and on the effects of the latter on investment.

We did find, however, an interesting exception. Our results worsen significantly when we use the enrollment ratio in secondary school ( $S E C$ ), rather than in primary school, to control for human capital. These negative results are probably due to the high degree of correlation between $S E C$ and $M I D C L A S S$, which is almost .6, i.e. almost double that between PRIM and MIDCLASS (see Table 4). Because of this pattern of correlations, it becomes hard to disentangle the effects of income distribution on secondary school enrollment and on SPI separately, while the problem is less acute when we use instead primary school enrollment.

The high correlation between secondary school enrollment and MIDCLASS suggest an additional channel through which income equality may enhance growth and accumulation: a wealthy middle class can afford to invest in higher education, while an impoverished one cannot. A more extensive empirical analysis of the relationship between 
inequality and investment in education is left for further research. ${ }^{16}$

An additional way of looking at the robustness of the results is to estimate the model using robust estimation methods. Roughly speaking, robust regression methods provide estimators that downweigh those observations that are "outliers". One dimension along which the robust estimators differ is the definition of an "outlier". Typically, an outlier is characterized by a large residual. We have chosen to estimate the SPI and INV equations by applying the bounded-influence estimator proposed by Krasker and Welsch (1982). The main reason for this choice is that this estimator identifies and downweighs outliers not only in the residuals' space, but also in the regressors' space. As shown by Krasker and Welsch (1983), an observation can be very influential and nevertheless the residual corresponding to that observation may be smaller than most other residuals. Since we are estimating a simultaneous-equation model, we implement the 2SLS version of the Krasker and Welsch estimator. ${ }^{17}$

Table 8 shows the Krasker and Welsch estimates of one of the basic specifications of the $S P I$ and $I N V$ equations, both with our index of socio-political instability and with Gupta's. Thus, columns (1a) and (1b) of Table 8 present the 2SLS Krasker-Welsch estimates of columns ( $3 a)$ and ( $3 b$ ) in Table 5 , while columns (2a) and (2b) present the 2SLS Krasker-Welsch estimates of the columns (3a) and (3b) in Table 6. One can see immediately that the point estimates of virtually all the coefficients are very similar, and in many cases almost identical, to those of the 2SLS estimators. The relative efficiency of the Krasker-Welsch estimator is always below .95 , which is often the value used in applied work. This is an indication that the estimates are indeed robust: the less efficient is the Krasker-Welsch estimator relative to the 2SLS estimator, the easier it is for an observation to be considered an outlier. ${ }^{18}$ These results are quite reassuring: although there are well

\footnotetext{
${ }^{16}$ See Perotti (1993) and Fernandez and Rogerson (1991) for theoretical discussions of this issue.

${ }^{17}$ Robust estimator for 3SLS have not been devised yet. See Krasker and Welsch (1982) and Krasker,Kuh and Welsch (1983) for a theoretical treatment of robust estimators, and Kuh and Welsch (1980) and Peters, Samarov and Welsch (1982) for some applications. The estimates of this section are obtained by applying a RATS program implemented in Perotti (1992).

${ }^{18}$ The reason why relative efficiencies are different in different equations is that we fixed the constant $c$ in Peters, Samarov and Welsch (1982) at a value of .55 rather than adjusting it every time to achieve a
} 
known measurement error problems in income distribution and political data, they are not of such a nature as to make the estimates of the model very sensitive to some particular observation.

Finally, we addressed the related issues of heteroskedasticity and misspecification due to measurement errors. We therefore conducted several tests of misspecification and heteroskedasticity on the same systems that appear in Table 5. A first rough indicator of the presence of misspecification possibly due to errors-in-variables problems is provided by a Hausman test using 2SLS and 3SLS estimates. The statistic was never significant at the $10 \%$ level. As to heteroskedasticity, we run a Breusch-Pagan test on the SPI equation, assuming that the error variance was proportional to the inverse of initial GDP. ${ }^{19}$ Again, the test was never significant. As an additional check, we reestimated the SPI equation applying White's heteroskedasticity correction, which in this IV framework becomes White's Two-Stage-Instrumental-Variables estimator (see White (1983)). Again, neither the coefficient estimates nor the $t$-statistics changed substantially.

\section{Conclusions.}

Income inequality increases socio-political instability which in turn decreases investment. After an extensive battery of robustness tests, we can conclude that these results in our sample of 70 countries are quite solid.

These results have positive and normative implications. From a positive point of view they suggest ar argument that might help explain different investment and growth performances in different parts of the world. Several countries in South East Asia have had very high growth rates in the post-WWII period. In the aftermath of the war, these countries had land reforms that reduced income and wealth inequality. Furthermore, and,

\footnotetext{
desired value of relative efficiency.

${ }^{19}$ If errors in measuring income distribution are more severe in poorer countries, for instance because the surveys are conducted with smaller budgets, the induced error variance will be inversely proportional to GDP.
} 
perhaps as a result of this reform, these countries have been relatively stable politically, compared to, say, Latin American countries. The latter, in turn, have had a much more unequal income distribution, more socio-political instability and less growth. A particularly good example of successful Asian countries are the "four dragons" (Hong Kong, Singapore, South Korea, and Taiwan). Unfortunately, because of data availability only Taiwan is included in our main sample. However, they would seem to fit our hypothesis, since these countries have had much more stability and much less inequality than, say, Latin American countries, which had a comparable GDP per capita in 1960.

From a normative point of view, our results have some implications for the effects of redistributive policies. Fiscal redistribution, by increasing the tax burden on capitalists and investors, reduces the propensity to invest. However, the same policies may reduce social tensions and, as a result, create a socio-political climate more conducive to productive activities and capital accumulation. ${ }^{20}$ Thus, by this channel fiscal redistribution might actually spur economic growth. Therefore the net effect of redistributive policies on growth has to weigh he costs of distortionary taxation against the benefits of reduced social tensions.

This paper, not unlike the related literature surveyed in the introduction, focuses on policy outcomes (investment, growth etc.) and relates them to socio-economic variables. The next step in this line of research is to look more explicitly at actual policy instruments, as Perotti (1992) has started doing. The link between politics and economic outcomes goes through policy choices, particularly, in this context, fiscal policy. Several questions are left open: what are the effects of income inequality on the degree of redistribution implemented in different political systems? Who actually benefits from such redistributions? What are the distributional effects of different spending programs? Do the very poor really benefit from government programs toward them? Answering these questions requires more disaggregated fiscal policy data than those used so far.

\footnotetext{
${ }^{20} \mathrm{~A}$ similar argument has been put forward by Sala y Martin (1992). A related argument, suggested by Fay (1993), focuses on illegal activities. Higher inequality fuels crime against private property; thus redistributive policies protect property rights by reducing crime.
} 
Table 1: Definition of variables and data sources.

This Table describes the data used in the regressions. All the data are from the BarroWolf [1990] data set, except for the income distribution data (which are from a variety of sources detailed in the Appendix) or unless otherwise indicated.

GDP: GDP in 1960 in thousands of 1980 dollars;

$P R I M$ : primary school enrollment rate in 1960, from Barro and Lee (1993);

$S E C$ : secondary school enrollment rate in 1960, from Barro and Lee (1993);

MIDCLASS: share of the third and fourth quintiles of the population in or around 1960;

URB: Urban population as percentage of total in 1960. Source: World Bank Tables;

$I N V$ : ratio of real domestic investment (private plus public) to real GDP (average from 1960 to 1985 );

PPPI: PPP value of the investment deflator (U.S. $=1.0$ ), 1960;

$P P P I D E$ : Magnitude of the deviation of the PPP value for the investment deflator from the sample mean, 1960;

SPI: index of socio-political instability, constructed using averages over 1960-85 of the variables that appear in the formula of equation (1);

SPIG: index of socio-political instability, constructed using annual data from the formula in Gupta (1990), average over 1960-85;

HOMOG: percentage of the population belonging to the main ethnic or linguistic group, 1960, from Canning and Fay (1993); 
Table 2: SPI index (sample 1960-85).

\begin{tabular}{lrlr} 
COUNTRY & SPI & COUNTRY & SPI \\
\hline \hline & & & \\
Tanzania & -1.24 & Turkey & 6.15 \\
Malawi & -3.36 & Panama & 2.80 \\
Sierra Leone & 9.21 & Brazil & -.43 \\
Niger & 3.19 & Colombia & -4.79 \\
Burma & 1.19 & Jamaica & -12.12 \\
Togo & 6.89 & Greece & 2.84 \\
Bangladesh & 8.74 & Costarica & -12.23 \\
Kenia & -1.24 & Peru & 7.74 \\
Botsawana & -10.21 & Iran & -.83 \\
Egypt & 1.68 & Mexico & -4.44 \\
Chad & 7.53 & Japan & -12.13 \\
India & -8.44 & Spain & -2.77 \\
Morocco & 2.03 & Iraq & 32.43 \\
Nigeria & 13.44 & Ireland & -11.70 \\
Pakistan & 10.85 & South Africa & -7.63 \\
Congo & 22.76 & Israel & -12.13 \\
Benin & 5.49 & Chile & .60 \\
Zimbabwe & -2.24 & Argentina & 34.04 \\
Madagascar & 2.13 & Italy & -7.18 \\
Sudan & 15.68 & Uruguay & 5.35 \\
Thailand & 9.76 & Austria & -12.13 \\
Zambia & -4.20 & Finland & -12.23 \\
Ivory Coast & -3.47 & France & -9.58 \\
Honduras & 5.16 & Holland & -12.13 \\
Senegal & -1.24 & U.K. & -6.54 \\
Gabon & 3.82 & Norway & -12.23 \\
Tunisia & -3.36 & Sweden & -12.13 \\
Taiwan & -3.47 & Australia & -12.13 \\
Philippines & -4.42 & Germany & -11.80 \\
Bolivia & 47.07 & Venezuela & 4.69 \\
Dom. Republic & 8.86 & Denmark & -12.23 \\
Sri Lanka & -10.31 & New Zealand & -12.23 \\
El Salvador & 8.55 & Canada & -12.13 \\
Malaysia & -11.68 & Switzerland & -12.23 \\
Ecuador & 21.32 & U.S.A. & -11.26 \\
& & &
\end{tabular}


Table 3: Summary statistics (sample 1960-85).

\begin{tabular}{lccccc} 
& NOBS & MEAN & STD. ERR. & MIN. & MAX. \\
\hline \hline & & & & & \\
INV & 70 & 19.49 & 7.42 & 6.82 & 36.91 \\
SPI & 70 & -.09 & 12.04 & -12.23 & 47.07 \\
SPIG & 70 & 18.43 & 5.01 & 11.41 & 28.17 \\
GDP & 70 & 2.07 & 1.90 & .21 & 7.38 \\
PRIM & 70 & 75.4 & 28.06 & 5.00 & 100.00 \\
SEC & 70 & 25.61 & 22.93 & .50 & 86.00 \\
URB & 64 & 39.51 & 23.33 & 4.00 & 82.00 \\
MIDCLASS & 70 & 33.01 & 5.55 & 20.10 & 41.90 \\
PPPI & 70 & .71 & .25 & .26 & 1.61 \\
PPPIDE & 70 & .20 & .15 & .006 & .86 \\
HOMOG & 67 & 58.90 & 29.53 & 7.00 & 99.00 \\
For definitions of variables and sources, see Table 1. & &
\end{tabular}


Table 4: Correlation matrix (sample 1960-85).

\begin{tabular}{|c|c|c|c|c|c|c|c|}
\hline & INV & SPI & SPIG & GDP & PRIM & SEC & URB \\
\hline INV & & -.39 & -.55 & .50 & .59 & .48 & .53 \\
\hline SPI & & & .81 & -.43 & -.34 & -.50 & -.29 \\
\hline SPIG & & & & -.62 & -.62 & -.61 & -.46 \\
\hline GDP & & & & & .62 & .73 & .78 \\
\hline PRIM & & & & & & .53 & .73 \\
\hline SEC & & & & & & & .65 \\
\hline
\end{tabular}

MIDCLASS PPPI PPPIDE AFRICA ASIA LAAMER HOMOG

\begin{tabular}{lccccccc}
\hline \hline & & & & & & \\
INV & .24 & -.30 & -.24 & -.28 & .12 & -.10 & .33 \\
SPI & -.38 & -.15 & .20 & .14 & -.10 & .32 & -.25 \\
SPIG & -.45 & -.11 & .14 & .37 & -.06 & .10 & -.48 \\
GDP & .48 & .10 & -.07 & -.47 & -.13 & -.05 & .39 \\
PRIM & .19 & -.01 & -.17 & -.65 & .18 & .25 & .61 \\
SEC & .57 & .11 & -.24 & -.46 & .13 & -.16 & .39 \\
URB & .36 & .04 & -.04 & -.62 & -.02 & .15 & .54 \\
MIDCLASS & & -.01 & -.33 & -.23 & -.02 & -.35 & .30 \\
PPPI & & & .28 & .05 & -.01 & -.08 & .07 \\
PPPIDE & & & & -.02 & -.03 & .21 & -.16 \\
AFRICA & & & & & -.17 & -.34 & -.56 \\
ASIA & & & & & & -.15 & -.10 \\
LAAMER & & & & & & & .34 \\
For definitions of variables and sources, see Table 1. & & & &
\end{tabular}

For definitions of variables and sources, see Table 1. 
Table 5: Investment and SPI equations, 1960-85.

\begin{tabular}{|c|c|c|c|c|c|c|c|c|}
\hline & INV & SPI & INV & SPI & INV & SPI & INV & SPI \\
\hline & (1a) & (1b) & $(2 a)$ & $(2 b)$ & $(3 a)$ & $(3 b)$ & (4a) & $(4 b)$ \\
\hline constant & $\begin{array}{l}19.55 \\
(5.07)\end{array}$ & $\begin{array}{l}23.17 \\
(2.19)\end{array}$ & $\begin{array}{c}20.75 \\
(5.34)\end{array}$ & $\begin{array}{l}31.98 \\
(2.93)\end{array}$ & $\begin{array}{l}20.78 \\
(5.64)\end{array}$ & $\begin{array}{c}19.80 \\
(1.71)\end{array}$ & $\begin{array}{c}20.78 \\
(5.64)\end{array}$ & $\begin{array}{l}31.51 \\
(3.06)\end{array}$ \\
\hline$P R I M$ & $\begin{array}{c}.10 \\
(2.97)\end{array}$ & $\begin{array}{c}-.14 \\
(-1.50)\end{array}$ & $\begin{array}{c}.09 \\
(2.64)\end{array}$ & $\begin{array}{c}-.19 \\
(-1.78)\end{array}$ & $\begin{array}{c}.09 \\
(2.80)\end{array}$ & $\begin{array}{c}-.23 \\
(-2.12)\end{array}$ & $\begin{array}{c}.09 \\
(2.80)\end{array}$ & $\begin{array}{c}-.23 \\
(-2.12)\end{array}$ \\
\hline$S P I$ & $\begin{array}{c}-.36 \\
(-1.96)\end{array}$ & & $\begin{array}{c}-.45 \\
(-2.62)\end{array}$ & & $\begin{array}{c}-.45 \\
(-3.08)\end{array}$ & & $\begin{array}{c}-.45 \\
(-3.08)\end{array}$ & \\
\hline PPPIDE & $\begin{array}{c}2.50 \\
(.45)\end{array}$ & & $\begin{array}{l}3.90 \\
(.68)\end{array}$ & & $\begin{array}{l}3.93 \\
(.71)\end{array}$ & & $\begin{array}{l}3.93 \\
(.71)\end{array}$ & \\
\hline$P P P I$ & $\begin{array}{l}-11.94 \\
(-3.46)\end{array}$ & & $\begin{array}{l}-12.81 \\
(-3.61)\end{array}$ & & $\begin{array}{l}-12.81 \\
(-3.71)\end{array}$ & & $\begin{array}{l}-12.83 \\
(-3.73)\end{array}$ & \\
\hline$G D P$ & & $\begin{array}{c}-1.62 \\
(-1.46)\end{array}$ & & $\begin{array}{c}-2.26 \\
(-1.93)\end{array}$ & & $\begin{array}{c}-1.54 \\
(-1.41)\end{array}$ & & $\begin{array}{l}-1.54 \\
(-1.41)\end{array}$ \\
\hline$M I D C L A S S$ & & $\begin{array}{c}-.60 \\
(-2.06)\end{array}$ & & $\begin{array}{c}-.62 \\
(-2.20)\end{array}$ & & $\begin{array}{c}-.31 \\
(-1.11)\end{array}$ & & $\begin{array}{c}-.60 \\
(-2.25)\end{array}$ \\
\hline$I N V$ & & $\begin{array}{c}.54 \\
(.95)\end{array}$ & & $\begin{array}{c}.55 \\
(1.03)\end{array}$ & & $\begin{array}{c}.51 \\
(1.04)\end{array}$ & & $\begin{array}{c}.51 \\
(1.04)\end{array}$ \\
\hline$A S I A$ & & & & $\begin{array}{c}-7.78 \\
(-1.37)\end{array}$ & & $\begin{array}{l}-2.12 \\
(-.37)\end{array}$ & & $\begin{array}{l}-2.12 \\
(-.37)\end{array}$ \\
\hline$A F R I C A$ & & & & $\begin{array}{c}-8.62 \\
(-1.94)\end{array}$ & & $\begin{array}{l}-4.04 \\
(-.96)\end{array}$ & & $\begin{array}{l}-4.04 \\
(-.96)\end{array}$ \\
\hline LAAMER & & & & & & $\begin{array}{c}10.38 \\
(2.47)\end{array}$ & & \\
\hline ORTLAAMER & & & & & & & & $\begin{array}{l}10.38 \\
(2.47)\end{array}$ \\
\hline s.e.e. & 5.87 & 11.85 & 6.30 & 11.54 & 6.31 & 10.99 & 6.31 & 10.99 \\
\hline
\end{tabular}


Table 6: Investment and SPIG equations, 1960-85.

\begin{tabular}{|c|c|c|c|c|c|c|c|c|}
\hline & INV & SPIG & INV & SPIG & INV & SPIG & INV & SPIG \\
\hline & (1a) & (1b) & $(2 a)$ & $(2 \mathrm{~b})$ & $(3 a)$ & $(3 \mathrm{~b})$ & $(4 a)$ & $(4 b)$ \\
\hline constant & $\begin{array}{r}34.15 \\
(3.73)\end{array}$ & $\begin{array}{l}30.83 \\
(8.46)\end{array}$ & $\begin{array}{l}37.94 \\
(4.16)\end{array}$ & $\begin{array}{c}32.86 \\
(8.61)\end{array}$ & $\begin{array}{c}39.92 \\
(4.36)\end{array}$ & $\begin{array}{c}31.15 \\
(7.39)\end{array}$ & $\begin{array}{l}39.92 \\
(4.36)\end{array}$ & $\begin{array}{l}32.80 \\
(8.72)\end{array}$ \\
\hline PRIM & $\begin{array}{c}.08 \\
(2.05)\end{array}$ & $\begin{array}{c}-.08 \\
(-2.59)\end{array}$ & $\begin{array}{c}.07 \\
(1.69)\end{array}$ & $\begin{array}{c}-.09 \\
(-2.46)\end{array}$ & $\begin{array}{c}.06 \\
(1.50)\end{array}$ & $\begin{array}{c}-.10 \\
(-2.49)\end{array}$ & $\begin{array}{c}.06 \\
(1.50)\end{array}$ & $\begin{array}{c}-.10 \\
(-2.49)\end{array}$ \\
\hline$S P I G$ & $\begin{array}{c}-.72 \\
(-2.24)\end{array}$ & & $\begin{array}{c}-.85 \\
(-2.68)\end{array}$ & & $\begin{array}{c}-.92 \\
(-2.90)\end{array}$ & & $\begin{array}{c}-.92 \\
(-2.90)\end{array}$ & \\
\hline$P P P I D E$ & $\begin{array}{l}-1.50 \\
(-.35)\end{array}$ & & $\begin{array}{l}-1.13 \\
(-.26)\end{array}$ & & $\begin{array}{c}-.94 \\
(-.21)\end{array}$ & & $\begin{array}{c}-.94 \\
(-.21)\end{array}$ & \\
\hline$P P P I$ & $\begin{array}{l}-10.24 \\
(-3.46)\end{array}$ & & $\begin{array}{l}-10.63 \\
(-3.61)\end{array}$ & & $\begin{array}{l}-10.83 \\
(-3.71)\end{array}$ & & $\begin{array}{l}-10.83 \\
(-3.71)\end{array}$ & \\
\hline$G D P$ & & $\begin{array}{c}-.90 \\
(-2.33)\end{array}$ & & $\begin{array}{c}-1.01 \\
(-2.46)\end{array}$ & & $\begin{array}{c}-.90 \\
(-2.26)\end{array}$ & & $\begin{array}{c}-.90 \\
(-2.26)\end{array}$ \\
\hline$M I D C L A S S$ & & $\begin{array}{c}-.23 \\
(-2.31)\end{array}$ & & $\begin{array}{c}-.23 \\
(-2.38)\end{array}$ & & $\begin{array}{c}-.19 \\
(-1.85)\end{array}$ & & $\begin{array}{c}-.23 \\
(-1.85)\end{array}$ \\
\hline$I N V$ & & $\begin{array}{c}.18 \\
(.90)\end{array}$ & & $\begin{array}{c}.16 \\
(.87)\end{array}$ & & $\begin{array}{c}.15 \\
(.84)\end{array}$ & & $\begin{array}{c}.15 \\
(.84)\end{array}$ \\
\hline$A S I A$ & & & & $\begin{array}{l}-1.47 \\
(-.74)\end{array}$ & & $\begin{array}{c}-.66 \\
(-.32)\end{array}$ & & $\begin{array}{l}-.66 \\
(-.32)\end{array}$ \\
\hline$A F R I C A$ & & & & $\begin{array}{c}-1.83 \\
(-1.17)\end{array}$ & & $\begin{array}{l}-1.16 \\
(-.75)\end{array}$ & & $\begin{array}{l}-1.16 \\
(-.75)\end{array}$ \\
\hline$L A A M E R$ & & & & & & $\begin{array}{l}1.46 \\
(.95)\end{array}$ & & \\
\hline ORTLAAMER & & & & & & & & $\begin{array}{l}1.46 \\
(.95)\end{array}$ \\
\hline s.e.e. & 5.28 & 4.09 & 5.39 & 4.04 & 5.47 & 4.01 & 5.47 & 4.01 \\
\hline
\end{tabular}


Table 7: Investment and SPI equations, alternative specifications, 1960-85.

\begin{tabular}{|c|c|c|c|c|c|c|}
\hline & INV & SPI & INV & SPI & INV & SPI \\
\hline & (1a) & (1b) & $(2 a)$ & $(2 b)$ & (3a) & $(3 b)$ \\
\hline constant & $\begin{array}{r}20.37 \\
(5.39)\end{array}$ & $\begin{array}{c}33.71 \\
(2.94)\end{array}$ & $\begin{array}{c}35.12 \\
(2.45)\end{array}$ & $\begin{array}{r}31.98 \\
(2.93)\end{array}$ & $\begin{array}{l}21.07 \\
(5.56)\end{array}$ & $\begin{array}{l}32.20 \\
(3.05)\end{array}$ \\
\hline$P R I M$ & $\begin{array}{c}.09 \\
(2.86)\end{array}$ & $\begin{array}{c}-.26 \\
(-2.06)\end{array}$ & $\begin{array}{c}.06 \\
(1.11)\end{array}$ & $\begin{array}{c}-.19 \\
(-1.78)\end{array}$ & $\begin{array}{c}.09 \\
(2.72)\end{array}$ & $\begin{array}{c}-.11 \\
(-1.08)\end{array}$ \\
\hline$S P I$ & $\begin{array}{c}-.44 \\
(-2.67)\end{array}$ & & $\begin{array}{c}-.75 \\
(-2.08)\end{array}$ & & $\begin{array}{c}-.44 \\
(-2.75)\end{array}$ & \\
\hline PPPIDE & $\begin{array}{l}4.86 \\
(.83)\end{array}$ & & $\begin{array}{l}4.95 \\
(.65)\end{array}$ & & $\begin{array}{c}3.97 \\
(-2.75)\end{array}$ & \\
\hline$P P P I$ & $\begin{array}{l}-12.98 \\
(-3.66)\end{array}$ & & $\begin{array}{l}-15.24 \\
(-2.92)\end{array}$ & & $\begin{array}{l}-13.09 \\
(-3.76)\end{array}$ & \\
\hline$G D P$ & & $\begin{array}{c}-2.76 \\
(-1.97)\end{array}$ & & $\begin{array}{c}-2.26 \\
(-1.93)\end{array}$ & & $\begin{array}{c}-2.27 \\
(-1.97)\end{array}$ \\
\hline$M I D C L A S S$ & & $\begin{array}{c}-.72 \\
(-2.33)\end{array}$ & $\begin{array}{c}-.32 \\
(-1.07)\end{array}$ & $\begin{array}{c}-.62 \\
(-2.20)\end{array}$ & & $\begin{array}{c}-.60 \\
(-2.07)\end{array}$ \\
\hline$U R B$ & & $\begin{array}{c}.12 \\
(1.04)\end{array}$ & & & & \\
\hline$I N V$ & & $\begin{array}{c}.69 \\
(1.17)\end{array}$ & & $\begin{array}{c}.55 \\
(1.03)\end{array}$ & & $\begin{array}{c}.39 \\
(.79)\end{array}$ \\
\hline HOMOG & & & & & & $\begin{array}{c}-.06 \\
(-1.00)\end{array}$ \\
\hline$A S I A$ & & $\begin{array}{c}-7.19 \\
(-1.22)\end{array}$ & & $\begin{array}{c}-7.78 \\
(-1.94)\end{array}$ & & $\begin{array}{l}-10.00 \\
(-1.58)\end{array}$ \\
\hline$A F R I C A$ & & $\begin{array}{c}-7.75 \\
(-1.45)\end{array}$ & & $\begin{array}{c}-8.62 \\
(-1.94)\end{array}$ & & $\begin{array}{c}-9.24 \\
(-2.07)\end{array}$ \\
\hline s.e.e. & 5.67 & 11.98 & 8.41 & 11.54 & 6.29 & 11.29 \\
\hline
\end{tabular}


Table 8: Investment and SPI equations, robust estimation, 1960-85.

\begin{tabular}{|c|c|c|c|c|}
\hline & INV & SPI & INV & SPIG \\
\hline & (1a) & (1b) & $(2 a)$ & $(2 b)$ \\
\hline constant & $\begin{array}{c}19.54 \\
(4.26)\end{array}$ & $\begin{array}{c}21.21 \\
(2.55)\end{array}$ & $\begin{array}{l}36.09 \\
(3.38)\end{array}$ & $\begin{array}{c}31.83 \\
(7.18)\end{array}$ \\
\hline$P R I M$ & $\begin{array}{c}.09 \\
(2.21)\end{array}$ & $\begin{array}{c}-.09 \\
(-1.07)\end{array}$ & $\begin{array}{c}.07 \\
(1.61)\end{array}$ & $\begin{array}{c}-.07 \\
(-1.68)\end{array}$ \\
\hline$S P I$ & $\begin{array}{c}-.47 \\
(-2.38)\end{array}$ & & & \\
\hline$S P I G$ & & & $\begin{array}{c}-.86 \\
(-2.32)\end{array}$ & \\
\hline$P P P I D E$ & $\begin{array}{l}1.78 \\
(.26)\end{array}$ & & $\begin{array}{c}.02 \\
(.003)\end{array}$ & \\
\hline$P P P I$ & $\begin{array}{l}-10.65 \\
(-2.55)\end{array}$ & & $\begin{array}{c}-9.05 \\
(-2.70)\end{array}$ & \\
\hline$G D P$ & & $\begin{array}{c}-2.03 \\
(-2.31)\end{array}$ & & $\begin{array}{c}-1.20 \\
(-2.56)\end{array}$ \\
\hline$M I D C L A S S$ & & $\begin{array}{c}-.28 \\
(-1.34)\end{array}$ & & $\begin{array}{c}-.22 \\
(-1.92)\end{array}$ \\
\hline$I N V$ & & $\begin{array}{c}-.04 \\
((-.11)\end{array}$ & & $\begin{array}{c}.11 \\
(.48)\end{array}$ \\
\hline$A S I A$ & & $\begin{array}{c}-5.76 \\
(-1.13)\end{array}$ & & $\begin{array}{c}.93 \\
(.34)\end{array}$ \\
\hline$A F R I C A$ & & $\begin{array}{c}-5.13 \\
(-1.54)\end{array}$ & & $\begin{array}{c}-.88 \\
(-.50)\end{array}$ \\
\hline s.e.e. & 6.44 & 10.88 & 5.41 & 4.00 \\
\hline
\end{tabular}

2SLS. t-statistics in parentheses. Number of observations: 70 . 


\section{Appendix: Sources of income distribution data.}

FLORA, PETER, FRANZ KRAUS and WINFRIED PFENNING [1987]: State, Economy and Society in Western Europe, Volume II, St. James Press, Chicago, IL;

JAIN, SHAIL [1975]: Size Distribution of Income: A Compilation of Data, World Bank, Washington, D.C.;

KUZNETS, SIMON [1963]: Quantitative Aspects of the Economic Growth of nations VIII: Distribution of Income by Size, Economic Development and Cultural Change, 2, $1-80$

LECAILLON, JACQUES et. al. [1984]: Income Distribution and Economic Development, ILO, Geneva;

PAUKERT, FELIX [1973]: Income Distribution at Different Levels of Development: a Survey of Evidence, International Labor Review 108 97-125;

PRYOR, FREDERIC L. [1989]: Income Distribution and Economic Development in Malawi: Some Historical Perspectives, World Bank Discussion Paper No. 36, Washington, D.C.;

UNITED NATIONS [1981]: A Survey of National Sources of Income Distribution Statistics, United Nations, Department of International Economic and Social Affairs, New York, NY;

VAN GINNEKEN, WOUTER and JONG-GOO BAK, eds. [1984]: Generating Internationally Comparable Income Distribution Estimates, ILO, Geneva;

WORLD DEVELOPMENT REPORT [1979]: The World Bank, Washington, D.C.; WORLD DEVELOPMENT REPORT [1986]: The World Bank, Washington, D.C.; 


\section{References}

AGHION, PHILLIP and PATRICK BOLTON [1991]: A Trickle-Down Theory of Growth and Development with Debt-Overhang, mimeo;

ALESINA, ALBERTO and DANI RODRIK [1991]: Distributive Politics and Economic Growth, NBER wp 3668;

ALESINA, ALBERTO and DANI RODRIK [1993]: Income Distribution and Economic Growth: A Simple Theory and Some Empirical Evidence, in: Cukierman, Alex, Zvi Hercovitz and Leonardo Leiderman: The Political Economy of Business Cycles and Growth, MIT Press, Cambridge;

ALESINA, ALBERTO, SULE OZLER, NOURIEL ROUBINI and PHILIP SWAGEL [1992]: Political Instability and Economic Growth, NBER working paper;

ALESINA, ALBERTO and GUIDO TABELLINI [1989]: External Debt, Capital Flights and Political Risk, Journal of Inernational Economics, 27, 199-220;

BANERIJEE, ABHIJIT and ANDREW NEWMAN [1991]: Risk Bearing and the Theory of Income Distribution, Review of Economic Stuides, 58 211-35;

BARRO, ROBERT J. [1990]: Government Spending in a Simple Model of Endogenous Growth, Journal of Political Economy 98 S103- 25;

BARRO, ROBERT J. [1991]: Economic Growth in a Cross-Section of Countries, Quarterly Journal of Economics 106 407-44;

BARRO, ROBERT J. and JONG-WAA LEE [1993]: International Comparisons of Educational Attainments, Harvard University, unpublished;

BENHABIB, JESS and ALDO RUSTICHINI [1991]: Social Conflict, Growth and 
Income Distribution, mimeo;

BENHABIB, JESS and MARK SPIEGEL [1992]: The Role of Human Capital and Political Instability in Economic Development, Economic Research Report, C.V. Starr Center for Applied Economics, New York University;

BERG, ANDY and JEFFREY SACHS [1988]: The Debt Crisis: Structural Explanations of Country Performance, Journal of Development Economics, 29, 271-306;

BERTOLA, GIUSEPPE [1991]: Market Structure and Income Distribution in Endogenous Growth Models, NBER wp 3851;

CANNING, DAVID and MARIANNE FAY [1993]: Growth and Infrastructure, Columbia University, unpublished;

CUKIERMAN, ALEX, SEBASTIAN EDWARDS and GUIDO TABELLINI [1992]: Seigniorage and Political Stability, American Economic Review 82 537-555;

DEVARAJAN, SHANTAYAMAN, SWAROOP VINAYA and HENG-FU ZOU [1992]: What Do Governments Buy?, unpublished manuscript, The World Bank; EDWARDS, SEBASTIAN and GUIDO TABELLINI [1991]: Political Instability, Political Weakness and Inflation: An Empirical Analysis, NBER wp 3721;

FAY, MARIANNE [1993]: Illegal Activities and Income Distribution: A Model with Envy, mimeo, Columbia University;

FERNANDEZ, RAQUELand RICHARD ROGERSON [1991]: On the Political Economy of Educational Subsididies, mimeo, Hoover Institutions;

GALOR, ODED and JOSEPH ZEIRA [1988]: Income Distribution and Macroeconomics, Brown University Working paper $89-25$ 
GUPTA, DIPAK K. [1990]: The Economics of Political Violence, Praeger, New York;

HIBBS, DOUGLAS [1973]: Mass Political Violence: a Cross-Sectional Analysis, Wiley and Sons, New York;

HUNTINGTON, SAMUEL [1968]: Political Order in Changing Societies, Yale University Press, New Haven;

JODICE, D. and D.L. TAYLOR [1988]: World Handbook of Social and Political Indicators, Yale University Press, New Haven;

KALDOR, NICHOLAS [1956]: Alternative Theories of Distribution, Review of Economic Studies 23, 83-100;

KUH, EDWIN and ROY E. WELSCH [1980]: Econometric Models and Their Assessment for Policy: Some New Diagnostics Applied to the Translog Energy Demand in Manufacturing, in S. Gass, ed.,: Proceedings of the Workshop on Validation and Assessment Issues of Energy Models, National Bureau of Economic Standards, Washington, D.C., $445-475$;

KRASKER, WILLIAM S. and ROY E. WELSCH [1982]: Efficient Bounded-Influence Regression Estimation, Journal of the American Statistical Association, 77 595-604;

KRASKER, WILLIAM S., EDWIN KUH and ROY E. WELSCH [1983]: Estimation with Dirty Data and Flawed Models, Ch. 11 in Griliches, Zvi and Michael Intrilligator, eds.: Handbook of Econometrics, North Holland, Amsterdam;

LONDEGRAN, JOHN and KEITH POOLE [1990]: Poverty, the Coup Trap and the Seizure of Executive Power, World Politics, 92, 1-24;

LONDEGRAN, JOHN and KEITH POOLE [1991]: Leadership Turnover and Uncon- 
stitutional Rule, unpublished;

MAURO, PAOLO [1993]: Political Instability, Growth and Investment, unpublished, Harvard University

MELTZER, ALLAN H. and SCOTT F. RICHARD [1981]: A Rational Theory of the Size of Government, Journal of Political Economy, 89 914-27;

MELTZER, ALLAN H. and SCOTT F. RICHARD [1983]: Tests of a Rational Theory of the Size of Government, Public Choice 41 403-18;

OZLER, SULE and GUIDO TABELLINI [1991]: External Debt and Political Instability, mimeo;

PEROTTI, ROBERTO [1992]: Fiscal Policy, Income Distribution, and Growth, mimeo, Columbia University;

PEROTTI, ROBERTO [1993]: Political Equilibrium, Income Distribution, and Growth, Review of Economic Studies, forthcoming;

PERSSON, TORSTEN and GUIDO TABELLINI [1990]: Is Inequality Harmful for Growth? Theory and Evidence, mimeo, Berkeley;

PETERS, STEPHEN C., ALEXANDER M. SAMAROV and ROY E. WELSCH [1982]: Computational Procedures for Bounded-Influence and Robust Regression, Technical Report No. 30, MIT Center for Computational Research in Economics and Management Science;

ROBERTS, KEVIN W.S. [1977]: Voting Over Income Tax Schedules, Journal of Public Economics, 8 329-40;

ROMER, TOM [1975]: Individual Welfare, Majority Voting, and the Properties of a 
Linear Income Tax, Journal of Public Economics 14 163-85;

SALA y MARTIN, XAVIER [1992]: Transfers, unpublished manuscript;

THEIL, HENRI [1971]: Principles of Econometrics, John Wiley, New York;

VENIERIS, YANNIS and DIPAK GUPTA [1983]: Socio-Political and Economic Dimensions of Development: A Cross-Sectional Model, Economic Development and Cultural Change, 31, 727-56;

VENIERIS, YANNIS and DIPAK GUPTA [1986]: Income Distribution and SocioPolitical Instability as Determinants of Savings: A Cross-Sectional Model, Journal of Political Economy, 96, 873-83;

VENIERIS, YANNIS and SAMUEL SPERLING [1989]: Saving and Socio-Political Instability in Developed and Less-Developed Nations, unpublished manuscript; 